KS. MARIUSZ LESZCZYÑSKI

\title{
ARCHIWUM ARCHIDIECEZJI W LUBACZOWIE
}

Adres Archiwum: 37-600 Lubaczów, ul. Mickiewicza 85, tel. 211-13. Dni i godziny urzędowania: wszystkie dni tygodnia oprócz niedziell i świąt, w godz. od 9 do 13.

\section{ORGANIZACJA ARCHIWUM *}

\section{NAZWA ARCHIWUM}

Zasoby „Archiwum Archidiecezjalnego obrządku łacińskiego we Lwowie" zostały w 1945 r. repatriowane ze Lwowa i złożne w kilku miejscach na terenie Polskiej Rzeczypospolitej Ludowej. W latach 1977-1978 przewieziono je na stałe do Lubaczowa i jednocześnie zmieniono nazwę tej instytucji na „Archiwum Archidiecezji Lwowskiej w Lubaczowie”.

\section{KIEROWNICTWO ARCHIWUM}

W okresie międzywojennym opieke nad Archiwum sprawował każdorazowy kanclerz Kurii Metropolitalnej, który był jednocześnie jego kierownikiem. Ostatnim kanclerzem przed wybuchem II wojny światowej. był ks. Zygmunt Hałuniewicz. Posiada on duże zasługi dla tej instytucji. On to zaangażowal w $1930 \mathrm{r}$. do pracy w Archiwum dra Stanisława Zajączkowskiego, a tuż przed wojną jeszcze Mariana Łempickiego. St. Zajączkowski Archiwum uporządkował i zinwentaryzował. Wynikiem tych prac jest sporządzony przez niego ,Inwentarz Archiwum Archidiecezjalnego" (Lwów 1930-31).

Po przewiezieniu Archiwum do Lubaczowa rozpoczęto w 1979 r. ponownie trud organizowania i porządkowania jego zbiorów. Zaangażowani do tego zostali najpierw ks. Stefan Weretczuk, następnie ks. Mikołaj Owsiański, a od 1983 r. także ks. Mariusz Leszczyński. Kierownictwo i opiekę nad Archiwum zlecił biskup Marian Rechowicz ks. St. Weretczukowi.

\section{POMIESZCZENIA ARCHIWUM}

Do $1939 \mathrm{r}$. Archiwum Archidiecezjalne mieściło się w pałacu arcybiskupów lacińskich we Lwowie przy ul. Czarnieckiego 32.

Najcenniejsze archiwalia, tzn. dokumenty pergaminowe i księgi konsystorskie przechowywano $\mathrm{w}$ osobnej szafie $\mathrm{w}$ kancelarii Kurii. Pozostałe zbiory złożone były w trzech pomieszczeniach suterenowych pałacu arcybiskupiego, o łącznej powierzchni ok. $60 \mathrm{~m}^{2}$. Magazyny archiwalne

* Plan niniejszego artykułu oparto na schemacie drukowanych sprawozdan ks. St. Librowskiego z działalności Archiwum Diec, we Włocławku. 
wyposażono w półki i światło elektryczne. Posiadały jednak za małą powierzchnię $\mathrm{w}$ stosunku do ciągle powiększanych zasobów.

Z chwila wybuchu II wojny śswiatowej Archiwum zostało wywiezione z budynku Kurii a wyposażenie magazynów archiwalnych zniszczone. Dopiero w 1944 r. archiwalia powróciły na dawne miejsce.

W październiku 1945 r. W ramach repatriacji Archiwum Archidiecezjalne oraz Archiwum i Bibliotekę Seminarium Duchownego przewieziono do Krakowa, Tarnowa i Kalwarii Zebrzydowskiej, gdzie byly przechowywane przez ponad 30 lat. Kuria Arcybiskupia w Lubaczowie nie dysponowała wówezas odpowiednimi pomieszczeniami, w których mogłaby umieścić całość Archiwum. Dopiero, kiedy wzniesiono nowy budynek Kurii, zwieziono w latach 1977-1978 Archiwum i Bibliotekę do Lubaczowa. W budynku zaplanowano i przygotowano odpowiednie pomieszczenia dla Archiwum i Biblioteki. Na magazyny archiwalne przeznaczono 4 sale: 2 na parterze i $2 \mathrm{w}$ podziemiach gmachu Kurii o następujących wymiarach: pierwsza od wejścia $4,2 \times 5,7 \mathrm{~m}$, druga $5,7 \times 6,5 \mathrm{~m}$, trzecia $5,7 \times 11 \mathrm{~m}$, czwarta $5,7 \times 2,6 \mathrm{~m}$. Eączna powierzchnia wszystkich sal wynosi $138,5 \mathrm{~m}^{2}$.

Magazyny archiwalne wyposażono w regały drewniane i metalowe, szafy, odpowiednie oświetlenie, zasłony okienne i ogrzewanie. Pomie-szczenia są suche, zimą opalane i dobrze zabezpieczone przed ogniem.

W ten sposób Archiwum Archidiecezjalne znalazło się we właściwych pomieszezeniach, stworzono odpowiednie warunki dla jego organizowania i porządkowania, a kwerendzistom umożliwiono korzystanie z jego zasobów.

\section{PRACOWNIA NAUKOWA I KSIĘGOZBIÓR PODRĘCZNY}

Pracownia naukowa przy Archiwum jest w stadium organizacji. W latach 1983-1984 przygotowano na ten cel pomieszczenie w sąsiedztwie magazynów archiwalnych. Służy ono jednocześnie jako kancelaria dyrektora Archiwum.

Organizowany jest również księgozbiór podręczny, na który składają się m.in.: książki z historii Polski i Kościoła w Polsce, słowniki, encyklopedie, prace o archiwum, źródła i opracowania dotyczące Archidiecezji Lwowskiej, rubrycele i schematyzmy. Archiwum posiada również komplety czasopism i miesięczników diecezji polskich, które mieszczą się $\mathrm{w}$ osobnym magazynie. Księgozbiór i czasopisma wymagają dalszego uzupelniania, a przede wszystkim skatalogowania.

\section{KANCELARIA ARCHIWUM}

Archiwum Archidiecezjalne przed 1939 r. nie posiadało własnej kancelarii. Napływającą korespondencję wpisywano do dziennika podawczego kancelarii Kurii i włączano chronologicznie do akt konsystorskich.

Po 1979 r., gdy rozpoczęto na nowo organizację Archiwum, postanowiono urządzić $\mathrm{w}$ nim odrębną kancelarię. Dotychczas założone zostały teczki dla alst dotyczących wlasności Archiwum, działalności administracyjnej, inwentaryzacji i pracy naukowej oraz ksicga udostępniania zasobów. W kancelarii przechowywane są również dokumenty o prze- 
szłości Archiwum, głównie o jego losach w okresie II wojny światowej i w latach powojennych, dawny inwentarz oraz najnowsze spisy $i$ indeksy zawartości jego zasobów.

\section{PRACA W ARCHIWUM}

\section{REWINDYKACJA, KONCENTRACJA I SCALANIE AKT}

W połowie grudnia 1939 r. gmach pałacu arcybiskupiego przejęły $\mathrm{w}$ użytkowanie władze radzieckie. Arcybiskup Bolesław Twardowski przeprowadził się do Księży Misjonarzy św. Wincentego à Paulo przy ul. Dwernickiego. Kuria znalazła pomieszczenia najpierw w parafii św. Antoniego a następnie w klasztorze OO. Franciszkanów Konwentualnych. Archiwum znajdujące się w pałacu arcybiskupim zostało upaństwowione i włączone do zbiorów Archiwum Państwowego. Całość zasobów przewieziono i ziożono w klasztorze OO. Dominikanów. Warto przy tym nadmienić, że akta personalne księży zostały zniszczone na polecenie arcybiskupa Twardowskiego, w pierwszych dniach września 1939 r. Slad tych archiwaliów pozostał jedynie $\mathrm{w}$ zachowanych niekompletnych indeksach.

Ponieważ do zasobów Archiwum Archidiecezjalnego zostały po II wojnie światowej włączone Archiwum i Biblioteka Seminarium Duchownego, stąd wypada wspomnieć tutaj o jego wojennych losach.

Seminarium Duchowne opuściło swój gmach przy ul. Czarnieckiego 30 już w pierwszých dniach grudnia 1939 r. Budynek przejęły w użytkowanie władze uniwersyteckie i przeznaczyły go na dom akademicki dla studentów medycyny. Alumni opuszczając gmach seminaryjny przenieśli Archiwum i Bibliotekę do pomieszczeń klasztoru OO. Franciszkanów Konwentualnych. Cenny księgozbiór patrologii Mign'a przekazal ks. rektor Stanisław Frankl na przechowanie do Ossolineum.

W tym czasie władze radzieckie przejęły także budynek Małego Seminarium, znajdujący się przy ul. Teatyńskiej 4.

Po wkroczeniu wojsk niemieckich do Lwowa, w czerwcu $1941 \mathrm{r}$. władze kościelne odzyskały gmach Małego Seminarium oraz pałac arcybiskupi. W Małym Seminarium zamieszkali klerycy. Tutaj także, pod kierunkiem prefektów ks. Mariana Rechowicza i ks. Wawrzyńca Mazura zwieźli Archiwum i Bibliotekę, znajdujące się w klasztorze OO. Franciszkanów.

Do pałacu sprowadził się Ksiądz Arcybiskup, kanclerz i urzędy kurialne oraz inni pracownicy Kurii. Skoro sytuacja we Lwowie trochę się unormowała, władze kościelne rozpoczęły starania o odzyskanie Archiwum Archidiecezjalnego, złożonego w klasztorze OO. Dominikanów. W piśmie z dnia 9 grudnia 1941 r. zwróciła się Kuria do władz niemieckich z prośbą o wydanie z Archiwum Państwowego we Lwowie ,akt kancelaryjnych, odpisów metrykalnych i archiwalnych, biblioteki i szaf należących do kancelarii Kurii, Seminarium Duchownego, Sądu Duchownego i Zarządu Dóbr Stołowych Arcybiskupich...".

W kilka dni później, dnia 17 grudnia, wysłano do władz niemieckich kolejne pismo z prośbą o zwrot pozostałych archiwaliów, nie wymienionych w piśmie poprzednim. Niemcy uwzględnili tylko częściowo prośbę Kurii Metropolitalnej. Wydali Archiwum Konsystorskie, Archiwum Za- 
rządu Dóbr Stołowych, Archiwalia Obce oraz część Archiwów Parafialnych. Z tego ostatniego działu nie zgodzili się wydać ksiąg i odpisów metrykalnych. Decyzję władz niemieckich przekazał Kurii p. Wąsowicz, urzędnik Archiwum Państwowego.

Ponieważ, jak stwierdzono, część Archiwum Archidiecezjalnego znajdowała się także $w$ Archiwum Państwowym przy ul. Jabłonowskich 1, Kuria Metropolitalna w piśmie z dnia 25 stycznia $1944 \mathrm{r}$. wystąpiła do władz niemieckich z prośbą o zwrot tych archiwaliów. Trudno jednak powiedzieć, jakie to były zbiory, kiedy i przez kogo zostały tam zdeponowane.

Po odzyskaniu obu zezwoleń Kuria Metropolitalna mogła przystąpić do zwożenia zasobów archiwalnych i złożenia ich w magazynach pałacu arcybiskupiego. Jak wynika $\mathrm{z}$ zachowanej dokumentacji akcję tę poprzedzily jeszcze długie starania u władz niemieckich o zdobycie odpowiedniego drzewa na sporządzenie nowych regałów, gdyż dawne uległy grabieży i zniszczeniu.

Dopiero w dniach od 7 do 10 lutego 1944 r. przewieziono Archiwum Archidiecezjalne z klasztoru OO. Dominikanów do Kurii. W akcji tej, pod kierunkiem ks. M. Rechowicza, brało udział 15 kleryków, kilku ministrantów i robotników.

Dalsze prace związane z zabezpieczeniem Archiwum podjęto w maju 1944 r. Do .Lwowa zbliżał się bowiem front wojenny. W wyniku bombardowania miasta przez lotnictwo radzicckie, poważnie został uszkodzony budynek Małego Seminarium. To zadecydowało, że zlożone tam archiwalia przeniesiono do podziemi kościoła seminaryjnego, jako miejsca bardziej bezpiecznego. Również część Archiwum Archidiecezjalnego wyniesiono z Kurii i złożono w podziemiach kościoła. Akcji tej dokonali klerycy Seminarium Duchownego.

Dalsze dzieje Archiwum związane są ściśle z akcją repatriacyjną Polaków ze Lwowa i okolic. W październiku 1945 r. przewieziono transportem kolejowym do Polski Archiwum Archidiecezjalne oraz zbiory archiwalne i biblioteczne Seminarium Duchownego. Fonieważ istniały poważne trudności ze znalezieniem wystarczającego pomieszczenia na przechowanie tych zbiorów $w$ całości, dlatego zdecydowano się podzielić je i złożyć w trzech miejscach: w klasztorze OO. Karmelitów Trzewiczkowych w Krakowie, w podziemiach plebanii przy kościele Serca Pana Jezusa w Tarnowie i w klasztorze OO. Bernardynów w Kalwarii Zebrzydowskiej, gdzie również znalazło dla siebie miejsce Seminarium Duchowne.

W ten sposób Archiwum uległo rozproszeniu. Miejsca, w których archiwalia złożono, były nicwielkie, pozbawione właściwej aklimatyzacji. Dlatego nie można było ułożyć ich na półkach i dokonać przynajmniej profilaktycznych zabiegów konserwatorskich. Archiwum pozostawione przez długie lata w takich warunkach, ulegało systematycznemu niszczeniu. Stąd wielką troską arcybiskupa Eugeniusza Baziaka było zgromadzenie zbiorów archiwalnych $w$ jednym miejscu i zabezpieczenie ich przed dalszym niszczeniem.

Zamiar ten został zrealizowany dopiero w 1956 r., kiedy rektorem Katolickiego Uniwersytetu Lubelskiego został kapłan lwowski ks. Marian Rechowicz. Wówczas arcybiskup Baziak i ks. Rechowicz zdecydowali, że archiwalia zostaną przewiezione do Lublina. 
W następstwie tego archiwalia zlożone w Krakowie, Tarnowie i Kalwarii Zebrzydowskiej, a także Bibliotekę Seminaryjną przywieziono na KUL. Część akt, książek i czasopism przetransportowano także do Oleszyc k. Lubaczowa.

Archiwum złożne na KUL znalazło nie tylko właściwe miejsce na przechowanie, ale z inicjatywy Ośrodka Archiwów, Bibliotek i Muzeów Kościelnych rozpoczęto mikrofilmowanie i opracowywanie jego zasobów.

Scalenie Archiwurn oraz możliwość jego organizacji zrealizowano dopiero w pełni w latach 1977--1978, kiedy ukończono budowę gmachu Kurii Arcybiskupiej w Lubaczowie. Wówczas do przygotowanych wcześniej pomieszczeń zwieziono wszystkie archiwalia złożone w Lublinie. Również część akt i ksiąg przechowywanych jeszcze w Kalwarii Zebrzydowskiej i Oleszycach przetransportowano do Lubaczowa.

W trakcie układania i wstępnego porządkowania zasobów zauważono brak wielu cennych archiwaliów, m.in. w dziale dokumentów pergaminowych i w zespole archiwów parafialnych. Księgi metrykalne wchodzące w skład tego zespołu, przejęte w 1939 r. przez władze radzieckie, nie zostały zwrócone Kurii przez Niemców w 1941 r. Co więcej, władze niemieckie zabrały również metryki z wielu parafii, zwłaszcza z tych, gdzie zamieszkiwała ludność pochodzenia niemieckiego. Po zaksończeniu repatriacji władze radzieckie część tych ksiąg metrykalnych przekazały do Polski. Dziś znajdują się one w Archiwum Akt Zabużańskich w Warszawie. Nieznana część metryk znajduje się także w Archiwach Państwowych $\mathrm{w}$ Przemyślu i Lublinie, a także $\mathrm{w}$ urzędach stanu cywilnego na terenie archidiecezji w Lubaczowie.

Aktualny zbiór ksiąg metrykalnych w Archiwum Archidiecezji Lwowskiej w Lubaczowie tworzą głównie metryki przekazane przez księży repatriantów, zakony i zgromadzenia zakonne, posiadające swoje placówki przed 1939 r. na terenie archidiecezji. Nie wszyscy jednak księża przekazali uratowane archiwalia do Kurii Arcybiskupiej w Lubaczowie. Wielu z nich, na polecenie władz administracji państwowej, oddało metryki do urzędów stanu cywilnego, które przekazano następnie do Archiwum Akt Zabużańskich w Warszawie.

Trudno jest na razie określić dokładnie wielkość strat, jakie poniosło Archiwum Archidiecezjalne w okresie II wojny światowej, w wyniku ewakuacji ze Lwowa i niewłaściwego przez długie lata przechowywania. Odnaleziony niedawno Inwentarz Archiwum Archidiecezjalnego opisujący jego przedwojenne zasoby, w porównaniu ze stanem realnym zbiorów, pozwoli w dużym stopniu wielkość tych strat ocenić.

Szczególnie ważnym etapem pracy w Archiwum jest koncentracja jego zasobów. Polega ona na gromadzeniu archiwaliów, znajdujących się w małych archiwach, np. parafialnych czy dekanalnych, w jednym Centralnym Archiwum Archidiecezjalnym.

Przed 1939 r. istniało we Lwowie, oprócz Archiwum Archidiecezjalnego, Archiwum Kapituły Metropolitalnej. Archiwum Kapituły było uporządkowane i zinwentaryzowane przed $1922 \mathrm{r}$. Natomiast w Archiwum Archidiecezjalnym rozpoczęto tego typu prace w latach 1930-1931. W tym celu Kuria Metropolitalna wydała szereg rozporządzeń do proboszczów, które zobowiązywały ich do nadsyłania archiwaliów parafialnych sprzed 1800 r. Dla ksiąg metrykalnych przyjęto datę końcową 
1783 r. W latach 1930 -1939 otrzymano takie archiwalia ze 163 parafii i dołączono je do tego typu akt przechowywanych już w Archiwum. W ten sposób, obok działu Archiwum Konsystorskiego, Archiwum Zarządu Dóbr Arcybiskupich i Archiwaliów Obcych, powstała czwarta grupa - Archiwa Parafialne, obejmujące łącznie 1121 jednostek (pergaminów, ksiąg, fascykułów, względnie plików akt).

Nie udało się natomiast przed $1939 \mathrm{r}$. zrealizować postulatu włączenia zasobów Archiwum Kapituły do Archiwum Archidiecezjalnego. Przyczyną był m.in. brak odpowiednich pomieszczeń w pałacu arcybiskupim. Archiwalia te nie zostały repatriowane. Dziś stanowią one część Centralnego Historycznego Archiwum URSR we Lwowie.

Inną ważną czynnością w porządkowaniu archiwum jest scalanie akt. Praca ta polega na połączeniu akt danej jednostki archiwalnej lub zespołu, rozbitych między różne zbiory.

Zespoły Archiwum Archidiecezjalnego uległy na przestrzeni wieków znacznemu rozbiciu. Część archiwaliów przechowywana była dawniej w palacu arcybiskupim $\mathrm{w}$ Obroszynie, gdzic, uległa zniszczeniu $w$ wyniku pożaru. Pozostałe zbiory przechowywano we Lwowie. Kilka pergaminów i ksiąg konsystorskich z niewiadomych przyczyn znalazła się w Archiwum Kapituly Metropolitalnej. Po 1930 r. przeniesiono je do Archiwum Archidiecezjalnego. Również kilka pergaminów przechowywanych w Muzeum Archidiecezjalnym sprowadzono do Archiwum.

W większym stopniu uległy rozbiciu archiwa dekanalne i parafialne. Wiele z nich zostało calkowicie zniszczonych w okresie II wojny światowej. Pozostałe, rozproszone w wyniku ewakuacji, tylko w szczątkowej formie zachowały się do czasów dzisiejszych. Archiwum Archidiecezji Lwowskiej w Lubaczowie prowadzi nadal akcję scalania archiwaliów. Na przykład w 1984 r. od Księży Misjonarzy z Krakowa otrzymano archiwum parafii Milatyn Nowy.

\section{KONSERWACJA AKT}

Pierwszą czynnością, jaką podjęto po przywiezieniu Archiwum do Lubaczowa, były podstawowe zabiegi konserwatorskie. Jak już wspomniano, archiwalia przez wiele lat przechowywano w niesprzyjających warunkach, w wyniku czego ulegały procesowi niszczenia. Część akt, złożonych w podziemiach plebanii przy kościele Serca Pana Jezusa w Tarnowie, zalała woda i tych nie udało się już uratować. Wszystkie fascykuły przed ułożeniem na regałach przeglądnięto, oddzielając akta zniszczone. Podobnych czynności dokonano $\mathrm{w}$ odniesieniu do dokumentów pergaminowych i ksiąg. Wydzielono te, które posiadały ślady zagrzybienia oraz działania insektów. Wszystkie zabiegi konserwatorskie ograniczyły się jedynie do czynności profilaktycznych, tj. do odkurzenia, oczyszczenia i zaopatrzenia w nowe olsładki tekturowe. Właściwe zabiegi konserwatorskie przewidziane są na najbliższe lata. Konieczna będzie przede wszystkim generalna dezynfekcja i dezynsekcja archiwaliów, a także prace introligatorskie. 


\section{PORZAZDKOWANIE AKT}

W latach 1930 - 1931 zostały przeprowadzone prace porządkowe w Archiwum Archidiecezjalnym. Wówczas podzielono Archiwum na cztery odrębne grupy, a te z kolei na działy: 1) Archiwum Konsystorskie (pergaminy, księgi konsystorskie, akta wizytacyjne i registratura konsystorska), 2) Archiwalia Parafialne (perganiny, księgi i fascykuły, względnie pliki luźnych akt), 3) Archiwum Zarządu Dóbr Arcybiskupich (księgi), 4) Archiwalia Obce (pergaminy, księgi, fascykuły, względnie pliki luźnych ak1).

W wyniku ewakuacji zbiory Archiwum uległy pomieszaniu, częściowemu zniszczeniu i zaginięciu. Włączone zostały natomiast archiwalia nowe wymienione $\mathrm{w}$, Inwentarzu" opracowanym przez St. Zajączkowskiego. Należą do nich m.in.: akta niektórych zakonów, Instytutu Ubogich, Seminarium Duchownego, akta dotyczące Kapituły Metropolitalnej. Dlatego porządkowanie Archiwum należy rozpocząc od nowa. Nie miałoby celu odtwarzanie dawnego układu, tym bardziej, że spotyka się on z wieloma zastrzeżeniami. Przedwojenny "Inwentarz" może posłużyć jako pomoc do identyfikacji zasobów, stwierdzenia braków i nabytków, stworzenia nowego ukladu Archiwum oraz do sporządzenia inwentarza realnego. Pomocą w porządkowaniu Archiwum będzie głownie najnowsza literatura archiwalna oraz osiągnięcia na tym polu innych archiwów diecezjalnych w Polsce.

Celem porządkowania będzie podzielenie całości zasobów archiwalnych na zespoły, a w poszczególnych zespołach nadanie aktom takiego układu, jaki miały w kancelarii (registraturze).

Obecny bowiem uklad Archiwum jest przypadkowy. Powstał on bez oparcia się na normach czy przepisach instrukcji, dotyczących organizacji Archiwum. Archiwalia rozmieszczono w następującym porządku:

Magazyn pierwszy od wejścia obejmuje dokumenty, mapy, plany, fotografie i mikrofilmy. Archiwum posiada tylko 50 dokumentow pergaminowych, najstarszy z $1419 \mathrm{r}$. Znaczna ich część uległa zniszczeniu na przestrzeni wieków i podczas II wojny światowej. Magazyn mieści ponadto:

1. Archiwum Konsystorza Metropolitalnego L.wowskiego (registratura konsystorska XIX-XX w.), obejmujące łącznie ok. $28 \mathrm{mb}$. akt;

2. Zespoły szczątkowe ok. czterystu archiwów parafialnych (XVII--XX w.), liczące ok. 14,5 mb. akt;

3. Ksiegi metrykalne ze 163 parafii archidiecezji lwowskiej (XVI- XX w.), w liczbie ok. 3 tysięcy (ok. $56 \mathrm{mb}$. akt);

4. Archiwum Archidiecezji w Lubaczowie (od 1946 r.).

Magazyn d r u g i mieści następujące archiwalia:

1. Archiwum Konsystorza Metropolitalnego Lwowskiego (registratura konsystorska, księgi konsystorskie, akta wizytacyjne XVI-XIX w.), liczące ok. $120 \mathrm{mb}$. akt;

2. Archiwum Zarządu Dóbr Arcybiskupich (XIX-XX w.), liczące ok. $16,5 \mathrm{mb}$. akt;

3. Archiwum Sądu Kościelnego (XIX-XX w.), liczące ok. $1 \mathrm{mb}$. akt;

4. Szczątkowe archiwalia Kapituły Metropolitalnej Lwowskiej (XVIII-XX w.), liczące ok. 0,5 mb. akt; 
5. Szczątkowe archiwa niektórych zakonów (XVII--XX w.), liczące ok. $3,5 \mathrm{mb}$. akt; akt;

6. Archiwum Instytutu Ubogich (XIX-XX w.), liczące ok. $6 \mathrm{mb}$.

7. Archiwum Seminarium Duchownego we Lwowie i Kalwarii Zebrzydowskiej (XVIII-XX w.), liczące ok. 15,5 mb. akt.

Wszystkie rękopisy Archiwum wynoszą łącznie ok. $260 \mathrm{mb}$. akt. W porównaniu z innymi archiwami diecezjalnymi Archiwum Archidiecezji Lwowskiej w Lubaczowie należy do większych tego typu zbiorów w Polsce.

Porządkowanie zasobów archiwalnych ograniczyło się na razie do posegregowania akt i próby określenia ich przynależności zespołowej. Kierowano się zasadniczo kryteriami zewnętrznymi.

W wielu wypadkach konieczna będzie klasyfikacja akt, tj. określenie ich przynależności zespołowej w świetle kryteriów wewnętrznych.

\section{INWENTARYZACJA AKT}

Inwentaryzacja akt stanowi odrębną, równorzędną porządkowaniu pracę $\mathrm{w}$ Archiwum $\mathrm{i}$ jest czynnością kończącą to porządkowanie. Polega na spisywaniu i opisywaniu akt w obrębie zespołu, względnie zespolów w zasięgu Archiwum.

Ponieważ w Archiwum Archidiecezji Lwowskiej w Lubaczowie nie rozpoczęto jeszcze właściwej inwentaryzacji, dlatego w niniejszym sprawozdaniu ograniczam się do przekazania kilku danych $z$ tej dziedziny z dawnych lat oraz do przedłożenia postulatów na przyszłość.

O najstarszych opisach akt zachowało się niewiele informacji. Wiemy, że na początku II połowy XIX w. istniał jakiś spis dokumentów. Zapewne musiał z niego korzystać Beda Dudik, znany historyk Moraw i archiwista, podczas swej podróży naukowej po Galicji w 1865 r., ponieważ w swym sprawozdaniu podał regesty 34 początkowych dokumentów (por. Archive im Königreiche Galizien und Lodomerien. Odb. z „Archiv für Kund Österreichischer Geschichtsquellen". T. 39: 1865 s. 141-146).

W swej publikacji wspomniał on również o kopiariuszu dokumentów przechowywanym w pałacu arcybiskupów. Z kopiariusza tego korzystał wydawca Aktów Grodzkich i Ziemskich, który przedrukował z niego szereg dokumentów (por. AGZ t. $2 \mathrm{nr} 6,14,15,18,31,38,40,41,43,47$, $67,75,90,98,104,110,117,124,126,130 ;$ t. $3 \mathrm{nr} \mathrm{81,91,97,126,128;}$ t. $4 \mathrm{nr} 113,119)$. Dzięki temu pozostal jedyny ślad po tych dokumentach, gdyż wspomniany kopiariusz nie zachował się do naszych czasów, a wiele dokumentów wymienionych w AGZ również uległo zniszczeniu.

Do czasów dzisiejszych nie zachowały się inne dawne spisy, katalogi czy inwentarze archiwalne. Prawdopodobnie pierwszy taki inwentarz szczegółowy, ujmujący całość zasobów archiwalnych opracował dopiero Stanisław Zajączkowski w latach 1930-1931. Inwentarz ten liczy 203 strony maszynopisu. Dwa jego egzemplarze przechowuje kancelaria Archiwum w Lubaczowie.

Inwentaryzacja obecnych zasobów archiwalnych przewidziana jest na kilka lat. Najpierw byłoby wskazane sporządzenie inwentarza kartkowego a następnie książkowego. Dotychczas opracowano jedynie indeks 
książkowy dla ksiąg metrykalnych, z podaniem sygnatury, rodzaju archiwaliów, dat krańcowych i uwag. Pozostałe archiwalia posiadają tylko spisy ich zawartości.

\section{UDOSTEPNIANIE AKT}

Po zakończeniu II wojny światowej Archiwum Archidiecezji Lwowskiej przez dlugie lata nie było udostępniane. Wyjątek stanowiły archiwalia zlożone na KUL, z których korzystali pracownicy naukowi oraz studenci. Ta część archiwum została zmikrofilmowana i opracowana przez Ośrodek ABMK. Mikrofilmy przekazano również do Lubaczowa.

Po 1979 r., kiedy Archiwum zostało zwiezione do Lubaczowa, powstały szersze możliwości udostępniania jego zbiorów. Ze względu na to, że Archiwum w dalszym ciągu jest $w$ stadium organizacji, porządkowania i opracowywania jego zasobów, istnieje trudność w sprawnym prowadzeniu kwerend. Mimo to archiwalia są udostępniane i wykorzystywane. Pomocą służą tu sporządzone indeksy, spisy zasobów archiwalnych oraz mikrofilmy.

Kwerendziści Archiwum rekrutują się z całej Polski, zarówno spośród duchowieństwa jak i osób świeckich. Badania naukowe dotyczą głównie tematyki kościelnej. Najczęściej wiążą się z pisaniem prac magisterskich i doktorskich. $Z$ tych ostatnich na uwage zasługuje rozprawa ks. Józefa Krętosza pt. Organizacja Archidiecezji Lwowskiej obrzqdku Zacińskiego od wieku XVI do 1772 roku, powstała na KUL.

Oprócz kweren'd prowadzonych w Archiwum udzielano takize informacji listowych osobom względnie instytucjom zarówno $\mathrm{z}$ kraju, jak i z zagranicy. Najczęściej dotyczyły one próśb o wypisy metrykalne.

Archiwum nie wypożycza archiwaliów i książek z księgozbioru podręcznego na zewnątrz. Wyjątek stanowią archiwalia przekazywane Ośrodkowi ABMK do mikrofilmowania.

\section{SPRAWOZDANIA Z PRACY W ARCHIWUM}

W kancelarii Archiwum prowadzona jest księga czynności tej instytucji. Dotychczas sprawozdań nie sporządzano i nie drukowano. Niniejsze za lata 1939-1984 jest pierwszym sprawozdaniem z działalności i czynności Archiwum. W przyszłości przewidziane jest systematyczne sporządzanie takich relacji.

\section{WAŻNIEJSZE OPRACOWANIA O ARCHIWUM}

1. Stanisław Z a ją c zkow ski: Archiwum Kapituły Łacinskiej we Lwowie. W: Arch. Tow. Nauk. we Lwowie, t. 2, Lwów 1923 s. 391-428.

2. St. $\mathrm{Z}$ a jąc z k. ow ski: Archiwum Kapitulne we Lwowie. „Archeion", nr 5: 1929 s. $31-36$.

3. St. Z Z j ą c z k ow s ki: Inwentarz Archiwum Archidiecezjalnego ob. łac. we Lwowie, sporządził... w latach 1930-1931 (Lwów 1931), mps ss. 203.

4. St. Zajączkow ski: Archiwum Archidiecezjalne ob. łac. we Lwowie, napisał... Lwów 1932. 
5. Stanisław Szurek: Archiwa Archidiecezji Lwowskiej ob. łac. Lwów 1934. (Odb. z „Collec. theol." t. 15: 1934 fasc. 3 s. 367-374).

6. O.A. Ku p c zyński, E.J. Ró ż ck i: Katalog perhamentnych dokumentiv Centralnoho Dierzawnoho Istorycznoho Archiwu URSR $u$ Lwowi 1233-1799. Kyjiw 1972 Wyd. "Naukowa Dumka” ss. 679 [M.in. 198 dokumentów z Arch. Kap. Lwow.]. 